Corrigendum

\title{
Corrigendum to "The Effect of Arch Height and Material Hardness of Personalized Insole on Correction and Tissues of Flatfoot"
}

\author{
Honglun Su, ${ }^{1,2}$ Zhongjun Mo,, Junchao Guo, ${ }^{1,2}$ and Yubo Fan $\mathbb{D}^{1,2}$ \\ ${ }^{1}$ Key Laboratory for Biomechanics and Mechanobiology of Ministry of Education, \\ School of Biological Science and Medical Engineering, Beihang University, Beijing 100086, China \\ ${ }^{2}$ Beijing Key Laboratory of Rehabilitation Technical Aids for Old-Age Disability, \\ Key Laboratory of Rehabilitation Technical Aids Analysis and Identification of the Ministry of Civil Affairs, \\ National Research Centre for Rehabilitation Technical Aids, Beijing 100176, China \\ Correspondence should be addressed to Yubo Fan; yubofan@buaa.edu.cn
}

Received 20 November 2017; Accepted 26 November 2017; Published 16 January 2018

Copyright (C) 2018 Honglun Su et al. This is an open access article distributed under the Creative Commons Attribution License, which permits unrestricted use, distribution, and reproduction in any medium, provided the original work is properly cited.

In the article titled "The Effect of Arch Height and Material Hardness of Personalized Insole on Correction and Tissues of Flatfoot" [1], the name of the first author was given incorrectly as Shonglun Su. The author's name should have been written as Honglun Su. The revised authors' list is shown above.

\section{References}

[1] S. Shonglun, Z. Mo, J. Guo, and Y. Fan, "The Effect of Arch Height and Material Hardness of Personalized Insole on Correction and Tissues of Flatfoot," Journal of Healthcare Engineering, vol. 2017, Article ID 8614341, 9 pages, 2017. 


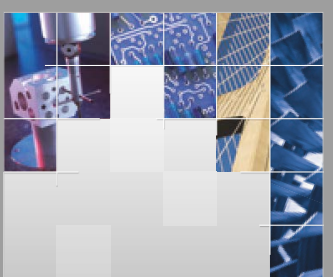

\section{Enfincering}
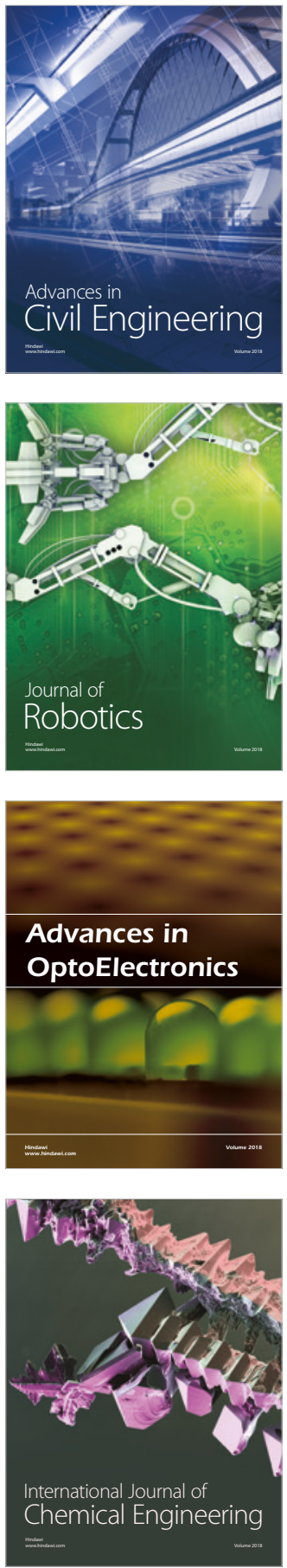

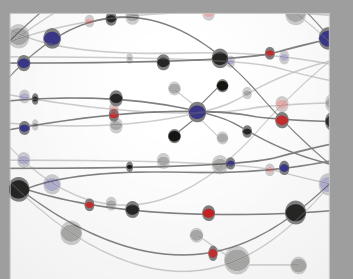

\section{Rotating \\ Machinery}

The Scientific World Journal

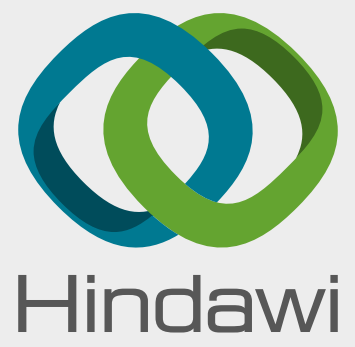

Submit your manuscripts at

www.hindawi.com
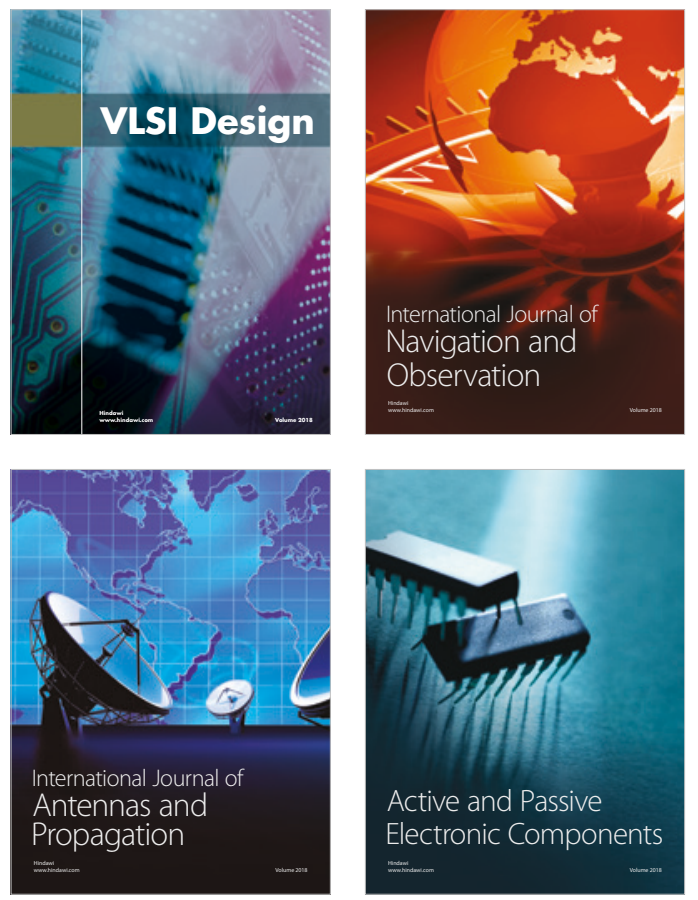
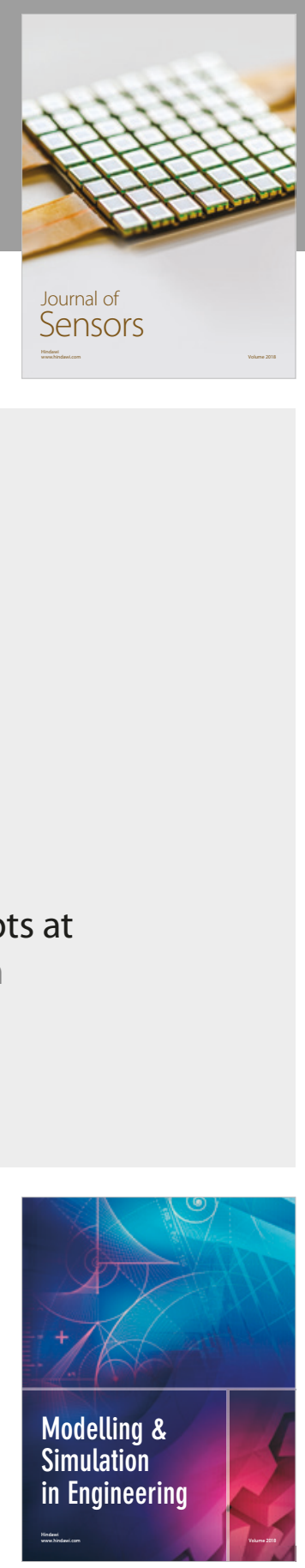

\section{Advances \\ Multimedia}
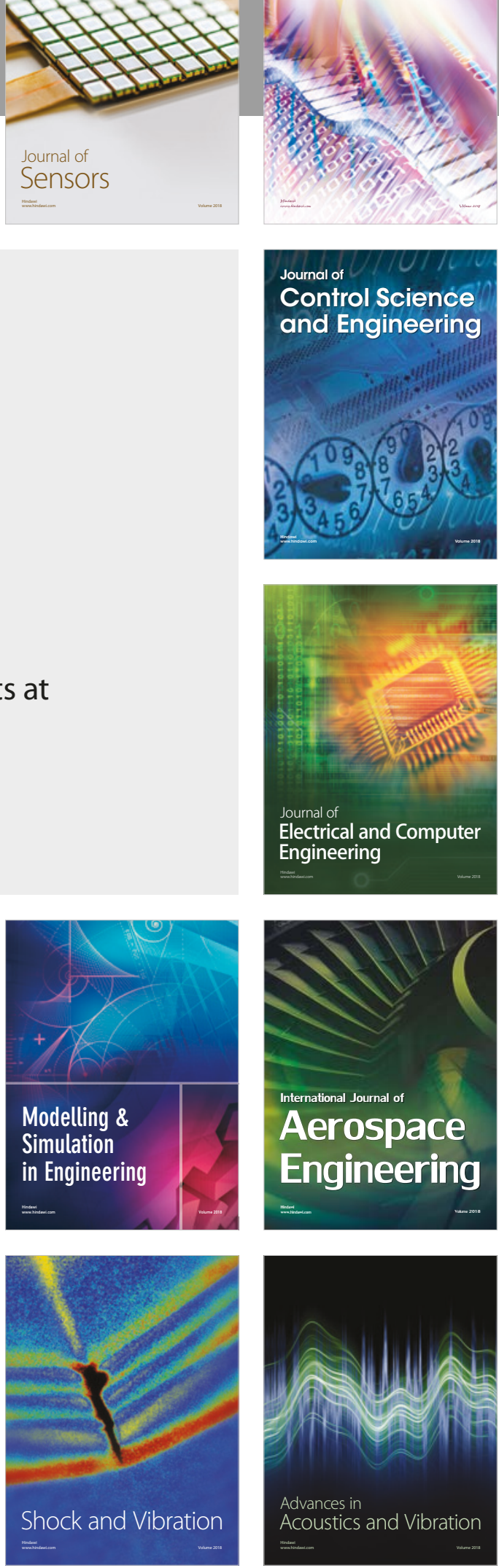